http://www.jfas.info

\title{
RANKING AND EVALUATING THE FACTORS AFFECTING THE SUCCESS OF MANAGEMENT TEAM IN CONSTRUCTION PROJECTS
}

\author{
M. Bahadori Zare ${ }^{1, *}$, A. Mirjalilii ${ }^{1}$ and M. Mirabi ${ }^{2}$ \\ ${ }^{1}$ Department of Construction Engineering and Management, Yazd Branch, Islamic Azad \\ University, Yazd, Iran \\ ${ }^{2}$ Department of Industrial Engineering, Meibod Branch, Ayatollah Haeri University, \\ Yazd, Iran
}

Published online: 15 May 2016

\begin{abstract}
Project success is one of the most important objectives and concerns of managers and people involved in a project. It also unifies the efforts of the project team. Success of the government construction projects aims to reduce cost and time, and increase quality and satisfaction of the society and government as the main customers. Many factors affect success of the construction projects. Identifying these factors contributes to successful implementation of the projects. The project management team is one of these important factors. The present study aimed to evaluate factors affecting success of the management team in the form of members' characteristics. To this aim, library and field research methods were used. The population consisted of 30 managers and professionals of the government successful projects as employer, consultant, and contractor. Data were collected through a questionnaire with 15 questions. Descriptive statistics was used to analyze the collected data.
\end{abstract}

Author Correspondence, e-mail: mehdi.bahadori@iauyazd.ac.ir doi: http://dx.doi.org/10.4314/jfas.v8i3s.251 
The results concerning the importance of team in organizing project showed that the most prominent features of the management team in Iran include team work skills and related ethics, the belief in customer satisfaction, and the absolute loyalty of the team to the project management and the company where they work.

Taking into account these features leads to the construction projects success.

Keywords: construction projects; management team; project success; management team features.

\section{INTRODUCTION}

Construction projects fact as the pulse of the society's economy. Due to these projects, public investment occurs, and cause economic growth together with the private sector investment. Activities related to construction projects in Iran were mainly followed up after formation of the economic and social programs and founded by the public budget. Therefore, success of such projects is considered as a criterion to measure and evaluate the government's performance. They reflect the efficiency and effectiveness of management practices in the country (Safari, 2011). Definition of the concept of project success has gradually evolved over the past 40 years. Most researches have focused on two dimensions of success: A) Measuring project success through the golden triangle criteria: cost, time, quality, B) Factors affecting success or success key factors including factors increasing chance of obtaining successful outcomes (Arbabi et al., 2009).

Assessing success factors of the government construction projects indicates that incompetence of managers and inefficiency of management teams are the major obstacles to construction projects success. These factors also affect other factors and lead to social dissatisfaction.

Assessing and evaluating one of the important factors in success of the government construction projects was one of the main objectives of the present study. The main practical goals of this study include: Presenting recommendations on the characteristics and conditions of the government projects management team members in order to achieve the project's objectives and satisfaction of the project's owner, i.e. the government. In this study, construction projects and management team were defined, the team features were assessed, and then their effects on success of the construction projects were examined.

\section{Construction Projects}

Construction projects in Iran are defined as the projects considered in the socio-economic development plans of the country based on comprehensive studies of major development. Their 
fund and budget are determined and financed in the country's annual budget. They are implemented under supervision of the Management and Planning Organization with the budget allocated by it.

Along with the formation of the national planning system, activities related to construction projects were organized in the form of implementation of the socio-economic development programs, in the framework of the construction budget allocation. A considerable amount of these projects funds, whose employer is the government, is spent on goods production, construction equipment, and installation. The most used implementation method of the construction projects was the traditional or three-factor method, which became prevalent since the Third Development Plan.

\section{Management Agents (Stakeholders)}

A stakeholder in an organization is any person or group that can affect or influenced by success of the organizational goals. The main agents of a project include employer, consultant, and the contractor.

As it is defined, stakeholders are a group or an organization that can affect the organization attitudes, resources or outputs, or influenced by the organization outputs. Interacting with stakeholders in line with the project objectives is one of the most important duties of the project manager that eventually will lead to the project success (Ameri, 2012).

\section{Project Management}

Project management generally means investigating, defining, conducting, organizing, designing and implementing a project's activities. Efficiency of project management system depends on the manager's knowledge about the project implementation mechanisms. The project manager deals with five basic elements: works, the people who do those works, money, equipment and facilities, and time. The project manager creates a value by correctly combining resources (money, equipment, facilities and human resources) on the context of time (the important non-physical resource). In successful projects, this value is more important than the resources. Generally, project management can be defined as follows: Project management is a proccess that conducts and organizes the project using the easiest way and the best results in order to achieve the project goals. Project management applies knowledge, skills, tools and techniques related to the activities of a project to meet its needs. 
Success of the project management. Project management applies knowledge, skills, tools and techniques to do project activities, meet the needs and fulfill the expectations of the stakeholders. Project management success consists of three basic components: 1- Concordance with the objectives including time, cost, and quality (the project inputs and outputs); 2- Quality of the project management process; 3- Meeting expectations of the shareholders connecting to the project management process.

Project management processes. Project management is a process of integrated and linked activities. Therefore, the experience of each of its aspects usually affects the other aspects. The interaction between these aspects can have positive and negative results. For example, a change in the work scope often increases the project costs. However, this can have a negative effect on the executives, quality of the product, or the service.

Process groups in project management. Project management processes are carried out in the form of one of the following five groups: Initiating processes, planning processes, executing processes, controlling processes, and closing processes. The connections between these groups can be seen in Figure B1 (Pmi, 2013).

One of the most important activities of the project manager in the initial process is team formation which can affect results of the other management processes and may lead to success or failure of the project.

\section{MANAGEMENT TEAM}

The project manager must be able to create coalition between different people involved in the project, including management, customers, construction team members, and suppliers. To achieve the project objectives, the manager should be able to negotiate and persuade people cleverly.

A team is a group of people working together to achieve a set of common goals. In the most traditional view, a team usually consists of a leader and some members working together on a specified issue. In today's institutions, teams are groups of people with shared goals. They usually do not have a formal leadership, members may not work together and they may also frequently change their mission and membership. Today, teamwork is considered as a philosophy of working together collectively towards an objective (Kiani, 2010). 


\section{METHODOLOGY}

In the most general classification, library and field research are considered as the research methods. In the present study, both of these methods were used. The present study is a nonexperimental survey (Bazargan, et al., 1998).

The present study is applied in terms of purpose, non-experimental descriptive (field survey) in terms of nature, and correlational in terms of methodology. Furthermore, library and field researches were used as integral components of scientific researches.

If one considers methodology as the conducting steps, the executive steps of this study were as follow: 1. Library studies (literature review); 2. Library studies (the initial identification and listing the primary and secondary variables); 3. The initial field study (deriving quantitative indices); 4. Data analysis; 5. Final identification and listing the variables related to strengths and weaknesses, opportunities, and threats; 6. Final field studies; 7. Data analysis; 8. Conclusions and recommendations; and 9. Typing (Khalilzadeh, 2013; Slahshour, 2013; Mosalman Yazdi, 2013).

\section{Tools and Data Collection Methods}

The questionnaire presented in the appendix was the most important data collection tool used in this study. The most data used in data analysis and hypotheses tests were collected through field survey using questionnaire and structured interview. Furthermore, it was tried to negotiate directly with the managers, and collect some data in the form of an interview, and also convince them to respond to some confidential questions in the questionnaire. It should be noted that each of the 30 respondents of the questionnaires and the structured interviews were the managers and employees of public and semi-public organizations. Their points of views were taken into account in general. The questionnaire included personal information of respondents (type of activity, educational level, and work experience) and 15 closed questions on "Investigation of the success factors in construction projects management teams", including 7 questions on project success, and 8 questions on the necessity of management team formation.

\section{The Population}

In this study, due to the needed expertise and experience to respond appropriately to the questions, the population consisted of the managers and executives of the government construction projects. Therefore, data were collected from all the managers of the projects (public and semi-public organizations), including 5 people from governmental organizations 
(employers), 10 staff from semi-public executives (employer, consultant and contractor), and 15 contractors of public and semi-public projects.

It should be noted that all members of the population in three categories of employer, consultant and contractor were educated (B.S. and higher levels) and all of them have been involved in the projects processes.

\section{VARIABLES}

The construction projects success. The concept of project success has been defined based on two dimensions: A) Measuring the project success through the golden triangle criteria: cost, time, and quality, B) Factors affecting success or success key factors including factors increasing chance of obtaining successful outcomes.

Features of the management team. The project justifying team must understand that people are at the heart of any process of change. So, communications and the association of people with the organization ensures success of change management. Key factors of change management consist of education, training, communication, team and leadership development.

Success of management agents in construction projects (employer management team, consultant, and employer). The project team is one of the main factors for the successful implementation of the project. Team members should be selected in a way that the team has all the necessary skills and be balanced. Using the wrong people to do a project, or ignoring the roles of individuals can have serious consequences. Considering interests and abilities of the team members for their work increases motivation, job satisfaction, teamwork efficiency, and likelihood of team success. To this aim, practical strategies should be used for evaluation, formation, development and arrangement of the project team, assess its strengths and weaknesses, and form a balanced team should via the proper tools.

Evaluating effective factors in the success of construction projects. In order to successfully finish a project, problems in the project should be solved in an appropriate way. Problem solving process includes defining the problem, analyzing its causes, collecting the necessary data, providing solution, formulating the alternative solutions, evaluating and prioritizing solutions, choosing the best solution, developing a practical plan, applying solutions, and evaluating the results. A person may have all the necessary skills to perform all these steps, but it is more realistic to expect that these skills exist in the team members. If one wants to solve the problem, 
not to create a hero, a proper team can be selected. The project manager is responsible for ensuring that the team has all the necessary skills and can solve the problems professionally. Although the ineffective use of the project team fails the project, but the project team, itself, is one of the factors contributing to success or failure of a project. Creating a team environment in which all members believe in their unity is important for the project success (Jiang \& Bin, 2002). Each project determines the team that should be formed, and effectiveness and performance of the team lead to the project success or failure. In most failed projects, the behavioral characteristics of the project team were effective. However, this does not refer to the behavior of every member, but the team's collective behavioral characteristics.

\section{Data Analysis}

After collecting data using the questionnaire, they all were coded and entered into the SPSS software. Then, data were classified, descriptive statistics were calculated, and finally, appropriate statistical tests were used to confirm or reject the hypotheses. For general and demographic data analysis (age, work experience and education), descriptive statistics were provided by the Excel software.

In the present study, the data related to the questions were analyzed using different inferential statistical methods. The data analysis was performed as follows:

1. The Cronbach alpha test was used to determine reliability of the questionnaire.

2. The Kolmogorov-Smirnov test was used to determine normality of the dependent variables distribution.

3. The one-sample t-test was used to test the hypotheses concerning the population mean.

The questionnaire used in this study was reliable due to the Cronbach's alpha coefficient of 0.883 .

Descriptive and inferential statistics were used to analyze data. According to the results obtained from the normal distribution test, since the significance level for the entire questionnaire was greater than the errors $(0.05)$, one can conclude that the variables (the project success and team management features) are normally distributed, as shown in Figures B2 and B3. Therefore, one sample t-test (parametric tests) can be used to test research hypotheses.

\section{Description of Data}

In order to understand the nature of the population and the variables, the data should be described before data analysis. Table A1 shows the descriptive characteristics of the entire sample 
including dispersion indices (standard deviation and variance) and the indices of central tendency (mean and median).

\section{Demographic Variables of the Respondents}

According to data, about $67 \%$ of respondents had a bachelor's degree, and $33 \%$ of them had a master's degree. Table A2 shows the frequency of the variable of respondents' organizational unit, and Table A3 shows the frequency of the variable of their work experience.

\section{Inferential Statistics}

In this section, the data obtained from the questionnaires containing some questions, several scales and different variables were examined. These questions and responses of the respondents were analyzed and lead to a better understanding of the research topic. Data analysis and statistical tests were conducted to confirm or reject the hypotheses. Since the Likert scale was used in this study, and the mean of each group was compared to the default mean of the population (3), one-sample t-test was applied.

The first hypothesis. The purpose of the government construction projects success is to reduce costs and time, and increase quality and satisfaction of the society and government as the main customers. One sample t-test was used to test this hypothesis. The hypotheses H0 and H1 were defined as follows:

H0: The purpose of the government construction projects success is not to reduce costs and time, and increase the quality and satisfaction of the society and government as the main customers.

H1: The purpose of the government construction projects success is to reduce costs and time, and increase the quality and satisfaction of the society and government as the main customers.

Descriptive characteristics of the variables are presented in Table A4, and Table A5 indicates comparison of the means using the results obtained from one-sample $t$ test.

The significance level of 0.05 represents the maximum value to reject the null hypothesis. If the obtained p-value is less than this value, the null hypothesis is rejected. However, if it is greater than 0.05 , the null hypothesis is accepted. Since, the obtained p-value in was 0.000 (less than 0.05$)$, the null hypothesis is rejected. According to the mean of the sample group, it can be said that: "The purpose of the government construction projects success is to reduce costs and 
time, and increase the quality and satisfaction of the society and government as the main customers".

The second hypothesis. Features and characteristics of the management team members are important in a construction project success.

One sample t-test was used to test this hypothesis and $\mathrm{H} 0$ and $\mathrm{H} 1$ were defined as follows:

H0. Features of the management team members are not important in construction projects success.

H1. Features of the management team members are important in construction projects success.

The descriptive characteristics of the variables are presented in Table A6. One sample ttest results to compare the mean of the sample group are presented in Table A7.

The significance level of 0.05 represents the maximum value to reject the null hypothesis. If the obtained p-value is less than this value, the null hypothesis is rejected. However, if it is greater than 0.05 , the null hypothesis is accepted. Since, the obtained p-value in was 0.000 (less than 0.05), the null hypothesis is rejected. According to the mean of the sample group, it can be said that: "Features of the management team members are important in the construction projects success.

The mean of ranking and description of the variables are presented in Table A8.

\section{Ranking of the Questions}

Friedman Test was used to rank the questions in the questionnaire. The results obtained from this test can be seen in Table A9.

As can be seen in Table A9, there is a significant difference between the ranking mean of the questions in p-value less than 0.05 . Therefore, it can be concluded that:

1. The importance and correlation of team formation in organizing the project has the highest mean of ranking with the of the project success.

2. Teamwork skills and teamwork ethics

3. Empowerment of the management team as one of the success factors in the status of project contractor is essential.

4. The belief in customers' satisfaction

5. The absolute loyalty of the team to the project manager or the company where they work. 


\section{CONCLUSIONS}

This study aimed to demonstrate some of the features of management team and their effects on construction projects success. Data were collected through questionnaires. At least 30 managers of successful construction projects participated in the present study. The results showed that formation of the management team had a positive effect on the construction projects success. The hypotheses are discussed separately in the following. Then, the recommendations and limitations of the study are presented.

The results showed that there was a significant positive correlation between the mean scores for the sample group and the mean of the population. In other words, it can be said that the purpose of the government construction projects success is to reduce costs and time, and increase the quality and satisfaction of government and society as the main customers. One of the reasons that can explain this hypothesis is that the project success depends on a balance between three factors including time, resources and results in order to provide an appropriate level of service to the customers. Project is at the service of customers' satisfaction. So, the three important factors must be considered, and an appropriate balance should be established between them. There is an equilibrium relationship between the above three factors (time, quality and cost). This means that a change is each factor causes changes in other factors. To achieve high quality, cost (and in some cases time) is increased; to reduce time of the project, the quality should be decreased or the costs and resources should be increased. It is evident that by reducing the cost, the quality is decreased, and implementation time is increased.

The results showed a significant positive correlation between the mean scores of the sample group and the mean of the population. In other words, features of the management team members are important in the construction projects success. One of the reasons that could explain the results of this hypothesis is that a team is a group of people working together to achieve a set of common goals. A project assigned to a team defines a set of specifications for a project team to be effective. These features, when are combined with the required specifications, form a necessary and sufficient set of features that a successful team must have. This issue leads to the correspondence of the team and the project. Execution power, harmony, good management of the changes, understanding each other, and strong communication describe the team main tasks including observation, innovation, promotion, development, organization, production, inspection, 
maintenance, and connection. These tasks are independent of the specific technical tasks. Each of these tasks are important to the project success.

\section{Prioritizing Success Factors in Management Teams of the Construction Projects}

The results obtained from the prioritizing of the management team success factors showed that there was a significant difference among the factors means, so that, the importance of team formation in organizing the project, teamwork skills and ethics, belief in the customers' satisfaction, absolute loyalty of the team to the project manager or the company where they work, team members' familiarity with the process of the project control (control of cost and time) had the maximum means, respectively. The minimum means belonged to the confirmation of each of the management team members by the company's headquarters, familiarity with the organizational behavior structure, and the correspondence between the management policy and the project charter.

\section{LIMITATIONS}

- This study was conducted on the government projects. So, the generalization to private companies should be done by caution.

- Data were collected through questionnaires. Other methods such as interviews and observation were not used.

\section{RECOMMENDATIONS AND FUTURE STUDIES}

\section{Applied Recommendations}

- It is recommended that researchers identify other success factors in the government projects.

- It is recommended that some workshops be held for managers and employees to know the importance of the project team.

- It is recommended to propose new methods to form a project team.

\section{Future Studies}

- This research can be conducted on other groups and samples with different cultures.

- Experimental and interventional research can be conducted to improve team projects.

- Exploratory research can be carried out to identify the factors intrude improvement of team projects. 
- The effects of family, economic and educational variables on the project success can be investigated

- Different models of team projects can be compared to improve success of the government projects.

- This research can be conducted on private companies and the results can be compared to the results obtained for the government companies.

\section{ACKNOWLEDGEMENTS}

Finally, I thank my dear professors, Dr. Alireza Mirjalili and Dr. Mohammad Mirabi, and the managers of the construction company.

\section{REFERENCES}

[1] Ameri, E. (2012). Stakeholder management in construction projects. The Eighth International Conference on Project Management, Kian management institute, Tehran.

[2] Arbabi, H. (2009). Conceptual model of the program success key factors. The Fifth International Conference on Project Management, Ariana Research Group, Tehran.

[3] Khalil Zade. (2010). A pamphlet on research methodology. Islamic Azad University of Sari.

[4] Kiani, H. (2010). Determining the role of value management in project management (project justification process). Unpublished Masteral thesis, Faculty of Economics and Administration, University of Mazandaran.

[5] Mosalman Yazdi, H. (2010). A pamphlet on research methodology, Yazd Branch, Islamic Azad University.

[6] Safari, M., I. (2011). The investigation of the barriers to successful implementation of construction projects. Unpublished Masteral thesis, Bonab Branch, Islamic Azad university.

[7] Salahshur. (2010). A pamphlet on research methodology.

[8] Tavakoli, A. (2007). What do we do with unfinished construction projects? Economic Research Journal, 26, 15-42.

[9] DQS, ISO Guid 73 :2009. In iso31000, germany: dqs, 2009

[10] feng guo, y. c. r. (2013). Effects of project governance structures on the management of risks in majorinfrastructure projects: A comparative analysis, International Journal of Project Management. 
[11] Pmi. (2013). Changes to the PMBOK® Guide (5th ed.) and What You Should Know. Toronto, Ontario: Robust.

[12] Turner, R. (1999). Handbook of project - Based management (2th ed.). Mc Graw - Hill.

\section{Appendix A}

\section{Tables}

\section{Table A1}

Descriptive Statistics of the Variables

\begin{tabular}{ccccc}
\hline Variable & Mean & Median & Standard deviation & Variance \\
\hline Project success & 4.3202 & 4.3744 & 0.35124 & 0.123 \\
\hline Management team features & 4.1250 & 4.1500 & 0.44755 & 0.200 \\
\hline
\end{tabular}

Table A2

Examining the Demographic variable of Organizational Unit

\begin{tabular}{ccc}
\hline Educational level & Percentage & Frequency \\
Employer & 23.3 & 7 \\
Consultant & 16.7 & 5 \\
Contractor & 60 & 18 \\
Total & 100 & 30 \\
\hline
\end{tabular}

Table A3

Examining the Demographic variable of Work Experience

\begin{tabular}{ccc}
\hline Work experience & Percentage & Frequency \\
\hline $\begin{array}{c}\text { Less than 5 } \\
\text { years }\end{array}$ & 6.7 & 2 \\
\hline 5-15 years & 36.7 & 11 \\
\hline 15-25 years & 33.3 & 10 \\
\hline 25-30 years & 23.3 & 7 \\
\hline Total & 100 & 30 \\
\hline
\end{tabular}


Table A4

Descriptive Characteristics of the Variables

\begin{tabular}{cccc}
\hline $\begin{array}{c}\text { Success of construction } \\
\text { projects }\end{array}$ & $\begin{array}{c}\text { Standard } \\
\text { deviation }\end{array}$ & Mean & N \\
& 0.35124 & 4.3202 & 30 \\
\hline
\end{tabular}

Table A5

Comparison of The Means Using the Results Obtained from One-Sample $t$ Test

\begin{tabular}{|c|c|c|c|c|c|c|}
\hline & \multicolumn{6}{|c|}{ Value $=3$} \\
\hline \multirow{3}{*}{$\begin{array}{l}\text { The success } \\
\text { of } \\
\text { construction } \\
\text { projects }\end{array}$} & $95 \%$ confi & ace level & & & Degree & \\
\hline & Maximum & Minimum & $\begin{array}{c}\text { Mean } \\
\text { difference }\end{array}$ & Sig. level & $\begin{array}{c}\text { of } \\
\text { freedo } \\
\mathrm{m}\end{array}$ & $\mathrm{t}$ \\
\hline & 1.4514 & 1.1890 & 1.32020 & 0.000 & 29 & $\begin{array}{c}20.58 \\
7\end{array}$ \\
\hline
\end{tabular}

Table A6

Descriptive Characteristics of the Variables

\begin{tabular}{ccccc}
\hline $\begin{array}{c}\text { Importance of features of the management team } \\
\text { members }\end{array}$ & $\begin{array}{c}\text { Standard } \\
\text { deviation }\end{array}$ & $\begin{array}{c}\text { Standard } \\
\text { deviation }\end{array}$ & Mean N \\
& 0.08171 & 0.44755 & $4.1250 \quad 30$ \\
\hline
\end{tabular}

Table A7

Comparison of The Means Using the Results Obtained from One-Sample $t$ Test

\begin{tabular}{|c|c|c|c|c|c|c|}
\hline \multirow{3}{*}{$\begin{array}{l}\text { Importance } \\
\text { of features of }\end{array}$} & \multicolumn{5}{|c|}{ Value $=3$} & \\
\hline & $95 \%$ confi & ice level & Mean & & Degree & \\
\hline & Maximum & Minimum & difference & & of & \\
\hline
\end{tabular}


M. Bahadori Zare et al.

\begin{tabular}{|c|c|c|c|c|c|c|}
\hline the & & & & & reedo & \\
\hline management & & & & & $\mathrm{m}$ & \\
\hline $\begin{array}{c}\text { team } \\
\text { members }\end{array}$ & 1.2921 & 0.9579 & 1.12500 & 0.000 & 29 & $\begin{array}{c}13.76 \\
8\end{array}$ \\
\hline
\end{tabular}

Table A8

The Mean of Ranking

\begin{tabular}{c|ccccc}
\hline Variables & $\begin{array}{c}\text { Maximu } \\
\mathrm{m}\end{array}$ & Minimum & $\begin{array}{c}\text { Standard } \\
\text { deviation }\end{array}$ & Mean & $\begin{array}{c}\text { Mean of } \\
\text { ranking }\end{array}$ \\
\hline $\begin{array}{c}\text { The } \\
\text { project }\end{array}$ & 4.86 & 3.29 & 0.35124 & 0.320 & 2.37 \\
success & & & & 24 & \\
\hline $\begin{array}{c}\text { Team } \\
\text { features }\end{array}$ & 4.90 & 3.00 & 0.44755 & 0.125 & 1.82 \\
\hline
\end{tabular}

Table A9

Friedman Test Results

\begin{tabular}{cc}
\hline No. & 29 \\
\hline Chi-square & 171.106 \\
\hline Degree of freedom & 34 \\
\hline Significance level & 0.000 \\
\hline
\end{tabular}




\section{Appendix B}

\section{Figures}

Figure B1

The Connections Between the Process Groups

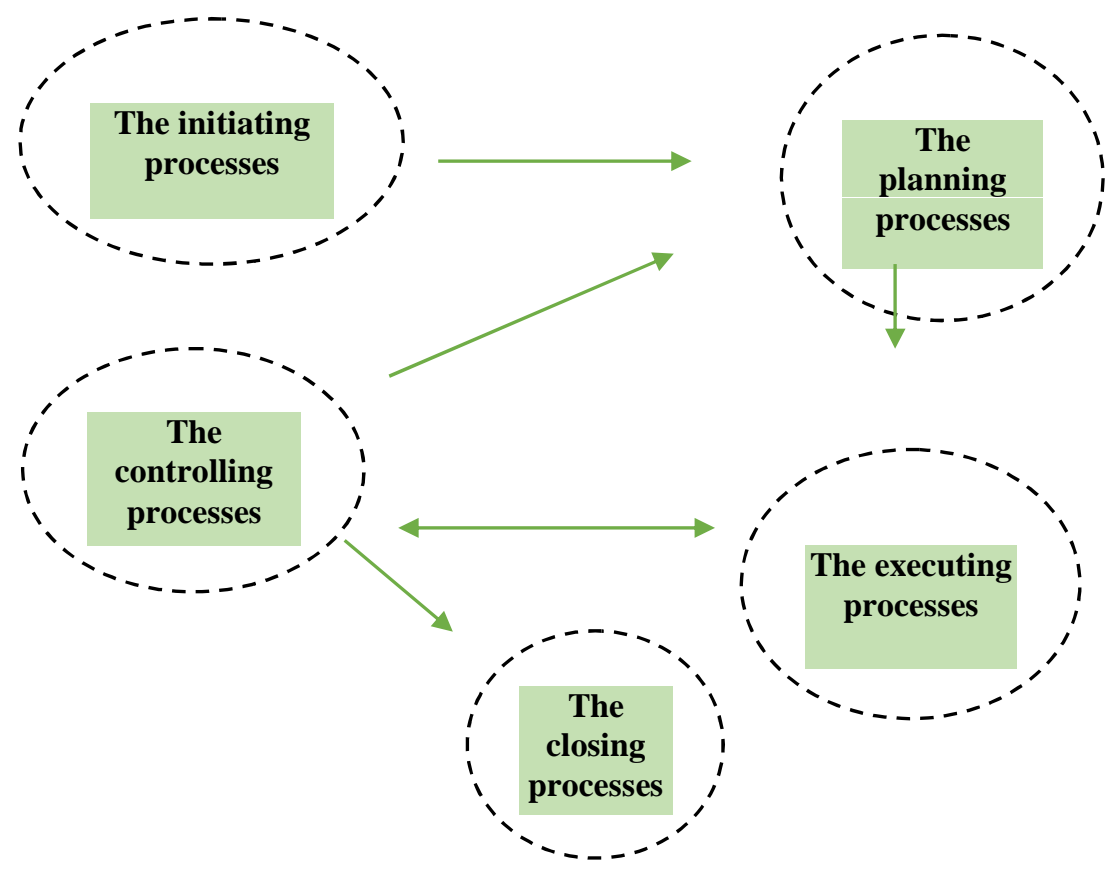

Figure B2

Normal Distribution of the Management Team Features.

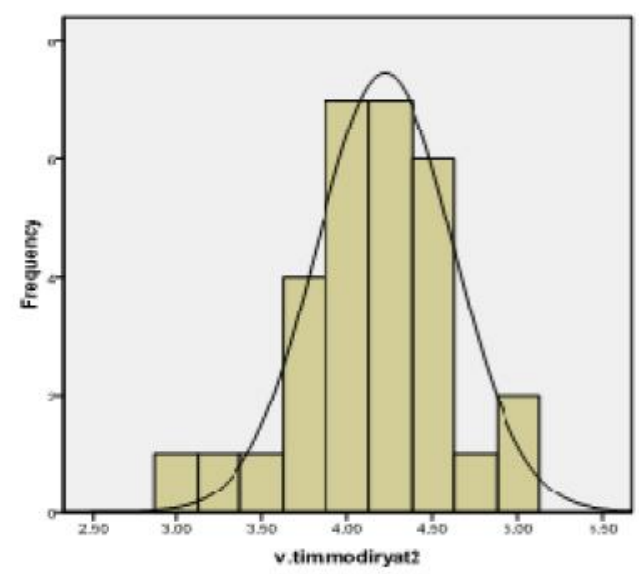

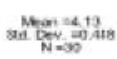


Figure B3

Normal Distribution of Project Success

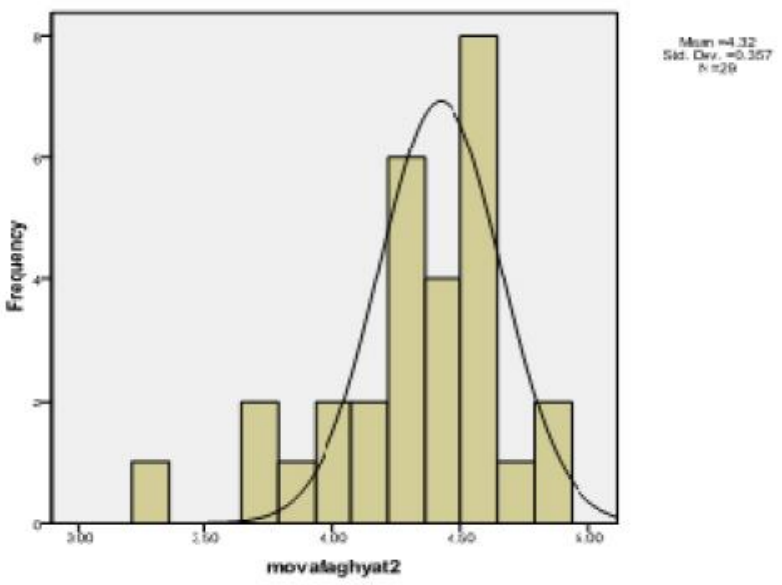

How to cite this article:

Bahadori Zare M, Mirjalili A and Mirabi M. Ranking and evaluating the factors affecting the success of management team in construction projects. J. Fundam. Appl. Sci., 2016, 8(3S), 614630. 